\title{
A Hybrid Method Using Factor Analysis and AHP on Passenger Purchase Decisions: The Case of Domestic Airlines in Turkey
}

\author{
Ozlem Atalik ${ }^{1} \&$ Emircan Ozdemir ${ }^{1}$ \\ ${ }^{1}$ Faculty of Aeronautics and Astronautics, Anadolu University, Eskişehir, Turkey \\ Correspondence: Emircan Ozdemir, Faculty of Aeronautics and Astronautics, Anadolu University, 2 Eylul \\ Campus, 26470, Eskişehir, Turkey. Tel: 90-222-322-2059/6962. E-mail: emircanozdemir@anadolu.edu.tr
}

Received: September 30, 2014

Accepted: November 28, 2014 Online Published: January 15, 2015

doi:10.5539/ibr.v8n1p14

URL: http://dx.doi.org/10.5539/ibr.v8n1p14

\begin{abstract}
This paper investigates factors affecting purchase decisions of domestic airline passengers and their preference priorities. Airline business is substantially dynamic as a service based business. Continuous change in passenger expectations and the increasing number of economic recessions in the world economies are compelling airlines to foresee and to design new services according to the priorities of passengers. In this study, the method uses factor analysis to describe factors affecting purchase decisions and subsequently Analytic Hierarchy Process defines the priorities among the rivals depending on the findings of first part. Output of the model provides us to specify the factors that affect priorities from the passengers' perspective. Hereby model can help to enhance items according to priorities. The hybrid approach is performed on a sample of 387 domestic passengers in Turkey through online questionnaires. On the other hand findings of the study depend on culture and should be adjusted for other cases.
\end{abstract}

Keywords: purchase decision, Analytic Hierarchy Process (AHP), airline marketing, customer choices

\section{Introduction}

Understanding the customer behavior and customer value has become extremely important in a globalizing world and also in a business environment that has become increasingly competitive with numerous economic crises to deal with. To be able to survive, managements have to quickly adapt to these conditions. Conducting marketing activities without reckoning this fact will have vital results for the airline enterprises. Customer value, which is the focus of modern marketing approach, always tends to change. This can easily be seen in the change of customer behaviors and purchase decisions.

Developed in the 1950s and gained momentum after the 1980s, the modern marketing approach has kept satisfying the customer needs and demands in the foreground, thus generating profit. This approach, accepted by the developed countries and gaining importance in our country day by day, provides customer satisfaction by understanding customers and their behaviors (Comert \& Durmaz, 2006; Durmaz, Reyhan \& Kurtlar, 2011).

The process named customer behavior can be described as a sequence of choosing a product or a service, purchasing, using, disposing decisions and actions related with this sequence. In the center of this mentioned process lies the main purchase decision. However, the purchase decision process doesn't end after the purchase event. In the period after the purchase, the customer builds up new ideas about the next purchase decision based on the previous consumption experience.

Benefits of studies on customer behavior can be easily and clearly seen in businesses especially which have high dynamics. In the airline business, that kind of studies are more important since the most customers are direct customers and the airline sector has extremely high dynamics. There is an intensive interaction especially between the customer and the enterprise in this sector. For this reason, understanding the customer behavior and the customer's purchase decision is very important for airlines to be able to carry out effective marketing activities.

There are mainly 4 factors affecting the customer purchase decision: Cultural, psychological, social and personal (Durmaz, 2008; Durmaz et al., 2011). Demographic characteristics are subsumed by personal factors. There are many studies on the effects of demographic characteristics on purchase decisions. Enterprises have used outputs of these studies to design new products or services to satisfy customers. But only demographic characteristics are 
not sufficient to explain the whole process by itself. So the new marketing mixes created on the basis of these studies cannot be effective and useful. Especially psychological factors have to be included in research to explain the whole process better.

In this study, psychological factors are also included as much as possible to explain the purchase decision process and relation of this process with the qualities of a given product or service. The first section includes theoretical information about the customer behavior and purchase decision process. In the second section, you can find a study that explains customer purchase decisions at airlines. The study contains a questionnaire designed for domestic passengers in Turkey. The questionnaire was accessed by the participants via the internet. The next step of the research contains a decision model from customers' perspective. For the decision modelling, the Analytic Hierarchy Process (AHP) technique is used.

\section{Consumer Behavior and Purchase Decision Process}

Consumer behavior is a process that includes the answers of questions about place, time, distribution, and price, supplier of product or service. Consumer behavior, which is a subpart of human behavior, is an aggregate of activities related to buying economical products or services (Odabasi, 1998).

The main purpose of the consumer behavior studies is researching how people decide while they spend their acquired resources. Also what, why, how, when, where and how often they purchase products or services are studied (Schiffman \& Kanuk, 1987).

\subsection{Factors Affecting the Consumer Behavior}

The consumer is always under the influence of environment, family, role groups, role and status etc. factors. These factors affect the purchase decision somehow.

Factors affecting consumer behavior can be gathered under 4 main categories shown below;

Cultural Factors: Cultural factors branch into three subheads as culture, subculture and social class.

Social Factors: Social factors branch into three subheads as reference groups, family, role and status.

Psychological Factors: Psychological factors are classified as motivation, learning, perception, intuition, attitude, personality, and belief.

Personal Factors: One of the important factors that affect consumer behavior is personal factors. They are segmented as age, life style, economic conditions, occupation, health, and personality (Durmaz, 2008).

\subsection{Purchase Decision Process}

Marketing specialists must forecast consumer needs, demands and behaviors to determine the target market, to improve their marketing strategies, to evaluate the future of markets and to make marketing mix decisions as correctly as possible (Islamoglu, 1999, 2003). To forecast all these, some questions must be answered in advance: "When consumers spend their money, what do they purchase? Which necessity underlies purchasing? When and how often do consumers purchase?" (Hoyer \& Macinnis, 1997).

Actually, consumer behavior contains three main steps: pre-purchase stage, purchase stage and post-purchase stage. Especially the market segmentation, choosing the target market, market positioning and composing new marketing mixes are done based on this process (Ercis, Unal \& Polat, 2007).

If we focus on the purchase decision process based on main consumer behavior steps, we obtain the following figure:

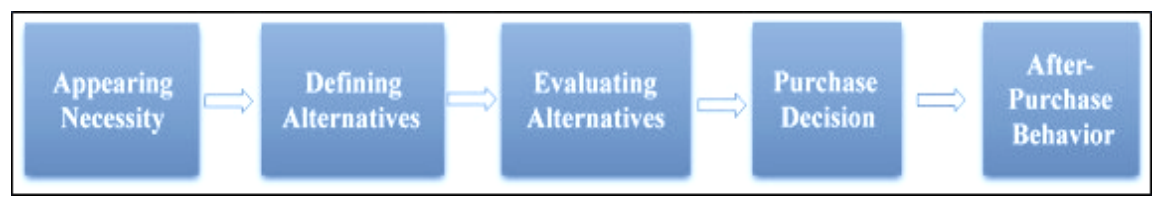

Figure 1. The purchase decision process

As shown in Figure 1, the purchase decision process starts with a consumer necessity. The necessity is pretty related to consumer value. The consumer wants to resolve this necessity and starts to search for alternatives. Among the alternatives, the nearest one to resolve necessity is chosen after evaluation. And thus the purchase decision occurs. But the purchase decision process doesn't end with making a decision. Also, after consuming a 
product or service, the consumer carries out behaviors according to the satisfaction level of the result. Finally, these behaviors will affect the repurchasing decisions.

\section{Factors Affecting the Purchase Decisions of Airline Customers}

Factors affecting consumer behaviors are investigated mainly in the previous section. But in our study, we need more effective and specific classification of factors. While specifically classifying the factors affecting the purchase decision, we have slightly split off from psychological and personal factors. Throughout this classification, commercial aspects are given in a particular emphasis. Because if the subject is making a purchase decision, the factors should also be commonly commercial (Atalik, 2009). For the airline business, these factors are handled below (modified from Gurses, 2006):

\subsection{Price Factor}

The price factor is one of the most important factors in air transportation. Because of the irregularity in the sector, price is an important variable for competitive advantage. In such an industry with lesser rivals which continuously monitor one another, price is extremely important (Gurses, 2006).

Price is already known to be important for customer pleasure. But it is not enough alone. Also the quality level should be as high as possible. If managements want to use this situation as an advantage, they should make their budget plans carefully. The price and quality have to be proportional to create an opportunity.

\subsection{Safety Factor}

All of the airlines operating in Turkey act under the control of Republic of Turkey Ministry of Transport and in accordance with the Turkish Civil Aviation Law. And also the Directorate General of Civil Aviation (DGCA) is a specific authority under the control of the Ministry of Transport. There are more specific and technical document.

Airlines and airports give points to safety on four main safety services: (THY, 1998)

- Passenger and baggage safety

- Cargo and post safety

- Catering safety

- Aircraft security search and protection

\subsection{Comfort Factor}

Generally, modifying airline schedules is pretty hard. Actually, making changes on schedules in short term is nearly impossible. Because of that, airlines usually outmaneuver this by modifying the comfort factor instead of changing the schedule. This process costs them less.

The comfort factor is mostly handled through cabin configuration and cabin crew. Some research also includes catering, but we handled it under another subtitle. Airlines increase seat comfort, make configuration changes, educate their cabin crew and develop other cabin related issues in order to improve comfort.

\subsection{Enterprise Image Factor}

It is obvious that customer pleasure is related to airline's image according to previous research. Purchase decision is generally affected by the enterprise image.

Enterprise image is the entire set of company related impressions and influences on target people. So all of the advertising and promoting activities, company logos, used colors, cabin designs, sales offices, airport lounges, service type variation etc. are effective on the enterprise image factor.

\subsection{Factors Related to Ground Handling}

Generally most ground handling facilities are not related to airlines. But they clearly affect the pleasure level of customers. Customers usually perceive ground handling services as integrated into other airline based factors. As a result of this situation, airlines try to offer more quality ground handling services to make a difference. If they don't provide ground handling by themselves, they have to cooperate with handling services suppliers.

Some of the advantageous ground handling services are special check-in desks for some passengers, reservation priority, special lounges, hotel and rent-a-car services, and urgent health services in airports. And also the waiting time in front of check-in desk is a directly effective variable on the ground handling factor.

\subsection{Punctuality Factor}

One of the most important prestige issues for airlines is punctuality. After the issue of price and safety, airline 
customers pay attention to punctuality the most. Also flight delay affects the quality level of service in customer view.

\subsection{Technology Factor}

Technology factor is approached in terms of cabin technology and aircraft newness. Due to the recent changes in communication and the internet, customers have started to pay attention to technological issues in airlines. For example, customers have started to check cabin designs and facilities before buying a ticket. And also most customers have a certain degree of information about the aircraft models. So they check about these technological issues just before choosing an airline.

\subsection{Catering Factor}

Cabin services and catering factors are very important topics for flight pleasure. Catering cannot be handled simply by ensuring food variety. The catering factor includes cabin crew's behaviors, friendliness, kindness etc. To be able to improve the catering service standards, cabin crew service standards must be developed first.

\subsection{Schedule Factor}

Airline schedules usually affect customer purchase decisions, because customers' flight hour and day choices must not be restricted. There should be many date options for the customers. So it means airlines would increase frequencies or set schedules according to the market's most preferred intervals.

\subsection{Online Service Factor}

Following the recent changes in technology and accessibility, customers have started to buy tickets via online channels. So the new trend is comparing airlines on the internet and purchasing tickets on web sites. Also call centers have become more important. For example, some customers don't want to give their credit card information on the internet. They prefer call centers. Furthermore, call centers serve to change flight dates, flight routes, luggage limits, etc. As a result, online service components have become more important and they will go on to become more strategic and extremely important in the future.

\section{Case of Turkish Domestic Passengers}

\subsection{Methodology}

\subsubsection{Study Design and Sample}

A survey approach was used to address the research objectives in this study. Questionnaires were online, simple, multiple-choice and implemented in the third quarter of 2014. Out of 392 returned questionnaires, 5 were discarded because of the respondent had never flown in domestic routes, or given invalid response. At $95 \%$ of confidence level, 5\% of margin of error and 50\% of expected proportion of individuals in the sample size, adequate sample size is equal to 385 according to formula below. Our study has enough sample size (387 respondents).

$$
n=t^{2} \cdot p \cdot q / d^{2}
$$

After the questionnaire part of study was completed, the model steps below in Figure 2 were followed. As it is seen in the figure, after the factor analysis step, the Analytic Hierarchy Process was used to find the best choice for our sample mass.

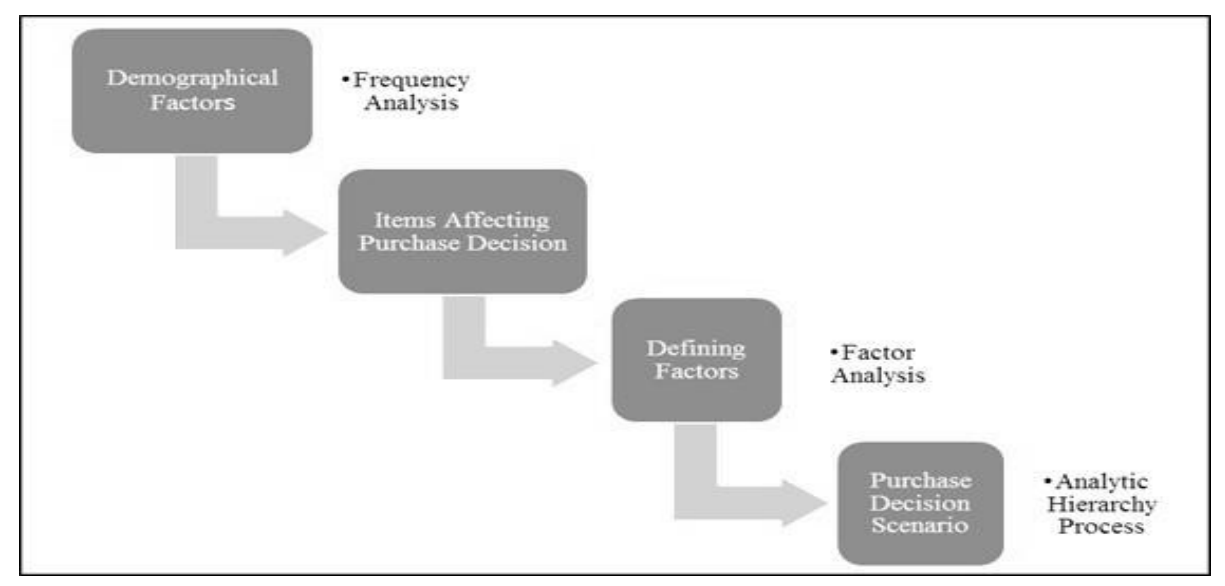

Figure 2. Model steps 


\subsubsection{Survey Instrument}

A questionnaire of 21 questions is used. First 4 questions are related to demographic factors and they are multiple-choice. For the demographic factor questions, segmentation has done according to previous studies. The following 3 questions are related to the customer's domestic flight experiences. For these questions we wanted the customer to have travelled in domestic routes before. And in the questions left, the factors affecting purchase decisions are analyzed. In these questions Likert type scale is used to survey the effect of these factors. Our Likert type scale is determined as ranging from $1=$ disagree strongly to $5=$ agree strongly.

\subsubsection{Purchase Decision Scenario}

After investigating the factor effects on purchase decision, according to outputs we have solved a decision problem. Outputs of factor analysis formed our decision problem inputs. And we have used the Analytic Hierarchy Process (AHP) for the purchase decision scenario. By using AHP, we have defined the priorities for acquired factor variances. For our model AHP hierarchy view is given in Figure 3. As it is seen in the figure, the goal is purchasing an airline ticket. There are some alternatives and the customer chooses one of them. After the factor analysis we have defined the factor groups and their variances. These variances have set our decision problem priorities. In order to identify these priorities we find the most preferred airline for our sample mass.

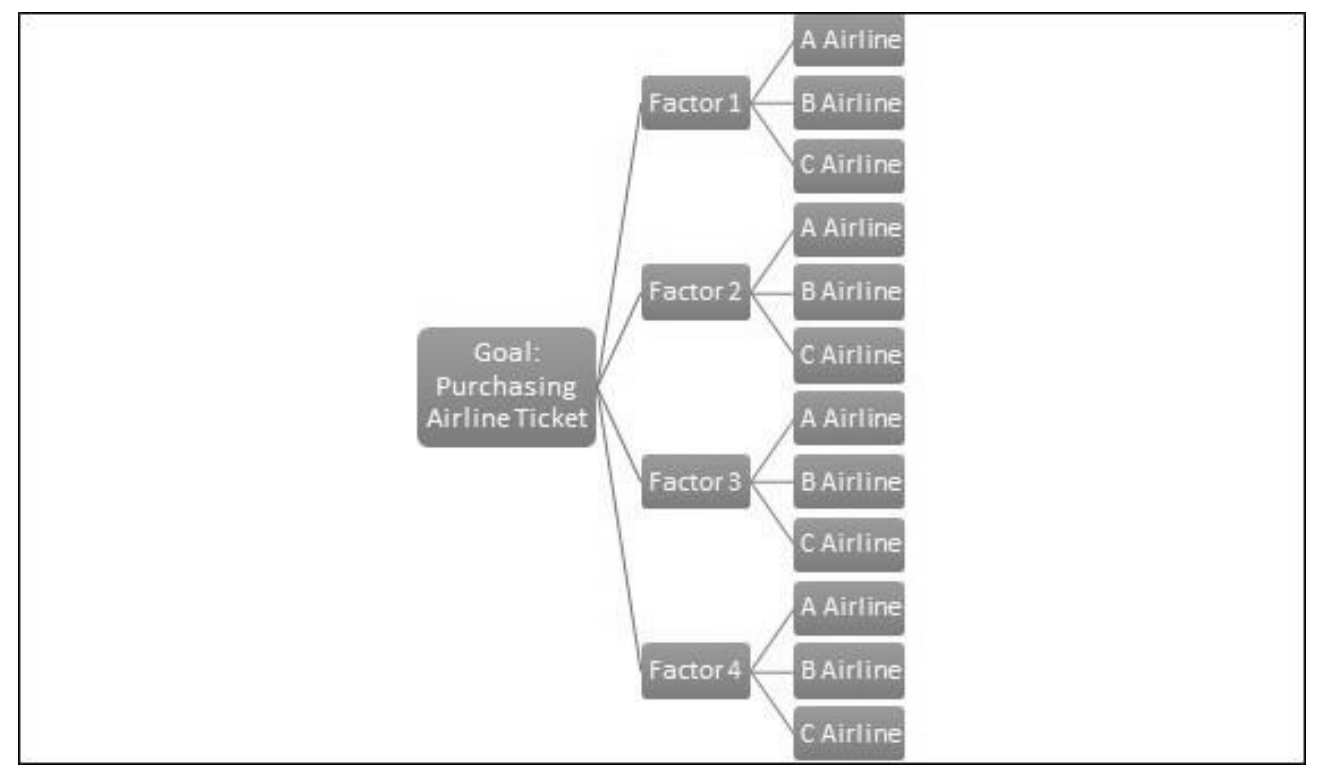

Figure 3. AHP hierarchy view

\subsection{Analyses and Results}

\subsubsection{Descriptive Statistics}

After collecting the questionnaire data, firstly we have analyzed the demographical factors. The demographical factors that we analyzed are gender, age, education level and income level. For the gender factor, 23.3 percent of the respondents are female and 76.7 percent are male. Other demographical factors are also classified and they are presented to the respondents in a multiple-choice way. Data frequencies are given in Appendix. According to our sample mass, most of the fliers have bachelor's degree and mid-income. Due to using a limited respondent area, some factors do not show homogenized results. If we were able to increase the number of respondents, they would be more homogenized.

After the analysis of this demographical factors, we focused on the items that affect purchase decisions regarding airlines. The descriptive statistics for these items are also given in Appendix. There are a total of 14 items affecting purchase decision in our study. Every item was measured in a question except for the corporate image item. We measured the corporate image item's affect in 2 questions and then the results of these two questions were combined. Participants generally chose high scales as it is seen in the descriptive statistics. It is a classical behavior about purchase decision. Customers naturally always want to buy the best. But it does not mean that all of our data is high and contaminated. Means are not so high and we can accept these as realistic levels. 


\subsubsection{Factor Analysis Results}

Evaluating 14 items separately is highly complex and we would not get a significant and rational output in this case. So we have to merge some factors if they are related and reduce the number of factors. This also helped us define priorities for the AHP. So we carried out a factor analysis to combine mean items and explain the factor effects on purchase decision.

Before the factor analysis we conducted a reliability test and calculated the Cronbach's alpha. This test was run for 14 items that affect the purchase decision. Our study is reliable at the level of 75.9\% (Cronbach alfa). It can be accepted significant enough for our study. Also Kaiser-Meyer-Olkin measure of sampling adequacy value is above 0.50 (KMO: 0.760) and Bartlett's test of sphericity significant at confidence level of 0.95 . These tests present that our items and data are factorable.

On the factor analysis step we have grouped 13 items under 4 main factor titles according to the analyses. We combined two items for Corporate Image. These groups are formed as shown below in Table 1.

Table 1. Factor groups

\begin{tabular}{cccc}
\hline Factor 1 & Factor 2 & Factor 3 & Factor 4 \\
(Marketing and Promotion Activities) & (Comfort Issues) & (Operational Specialties) & (Price) \\
\hline Advertisement & Catering & Schedule \\
Corporate Image & Cabin Technology & Flight Connection & \\
Call Center & Shuttle & Baggage & \\
FFP & & Punctuality & \\
Web Site & & & \\
\hline
\end{tabular}

There are four main factors now. Next step is naming the factor groups. When you look at factor 3 , most of the sub-factors are operational. So, factor 3 is "Operational Specialties". At factor 1 all the sub-factors are related with promotion and marketing. The call center may be eliminated here, but almost every commercial airline cares its customer contact. So call centers are not totally separated from marketing activities. Factor 1 is named as "Marketing and Promotion Activities". Factor 2 is obviously "Comfort Issues". And factor 4 is "Price" solitarily.

Factor analysis and new groups of factors explain $54.696 \%$ of the total variance. Considering that demographical factors are out of this calculation and only 13 factors are included, this percentage is significant for our study. New factor groups and these four main factors' variances will become our purchase decision problem inputs. The new factor groups' variances in total variance and normalization process to prepare them for use in decision problem can be seen in Table 2 below.

Table 2. New factor groups' variances and normalization

\begin{tabular}{cccccc}
\hline & Factor 1 & Factor 2 & Factor 3 & Factor 4 & Normalization Coefficient \\
\hline Ratio & 16.004 & 15.755 & 14.855 & 8.082 & 1.828 \\
Normalized Ratio & 29.260 & 28.805 & 27.159 & 14.776 & \\
\hline
\end{tabular}

\subsubsection{AHP Results and Discussion of the Model}

After the factor grouping, the next step is solving the purchase decision problem. According to the normalized variances given in Table 2, we created pairwise comparison matrix to handle the situation as an AHP problem. Our four main factor groups are the four main criteria in the AHP. Criteria pairwise comparison matrix is given in Table 3. 
Table 3. Pairwise comparison matrix for criteria

\begin{tabular}{ccccc}
\hline & F1 & F2 & F3 & F4 \\
\hline F1 & 1 & 2.81 & 2.98 & 5.49 \\
F2 & 0.36 & 1 & 2.94 & 5.40 \\
F3 & 0.34 & 0.34 & 1 & 5.09 \\
F4 & 0.18 & 0.19 & 0.20 & 1 \\
\hline
\end{tabular}

In Table 3, comparison values are pairwise proportions of the variances. The comparison values are multiplied by 2.77 in order to concretize differences between factors. This parameter is the optimum number which keeps consistency ratio (CR) below 0.10 (Benitez, Delgado-Galvan, Gutierrez, Izquierdo, 2011). CR is calculated by dividing the consistency index (CI) into the random index (RI). Also CR should be lower than 0.10 for a consistent and logical comparison (Saaty, 2003). In our multiplied matrix, CR is equal to 0.10. CR calculation formulas are given below.

$$
\begin{gathered}
\text { Consistency Ratio }(C R)=\text { Consistency Index }(C I) / \text { Random Index }(R I) \\
\qquad I=\frac{\lambda_{\max }-n}{n-1}
\end{gathered}
$$

The diagram of our decision problem is already given in Figure 3. As can be seen in the figure, there are 4 criteria and 3 alternatives. So we have one criterion pairwise comparison matrix to reach the goal. And also we have 4 pairwise comparison matrices for each criterion.

In the decision problem three example airlines are given. These examples are generated by considering three real domestic airlines. But their names are kept hidden and we handle them just as examples. There are a total of three example airlines and the first has superior operation, the second one has superior comfort issues and the last one has low prices. These example airlines' score matrix is given in following Table 4 .

Table 4. Example alternatives score matrix

\begin{tabular}{lcccc}
\hline & F1 & F2 & F3 & F4 \\
\hline A Airline & 6 & 4 & 7 & 3 \\
B Airline & 8 & 9 & 5 & 4 \\
C Airline & 5 & 2 & 4 & 8 \\
\hline
\end{tabular}

Table 5. Alternatives' comparison matrices

\begin{tabular}{cccccccccccccc}
\hline & \multicolumn{3}{c}{ Factor 1 } & \multicolumn{3}{c}{ Factor 2 } & \multicolumn{3}{c}{ Factor 3 } & \multicolumn{3}{c}{ Factor 4 } \\
\cline { 2 - 30 } & A & B & C & A & B & C & A & B & C & A & B & C \\
\hline A & 1 & 0.75 & 1.2 & 1 & 0.44 & 2 & 1 & 1.4 & 1.75 & 1 & 0.75 & 0.38 \\
B & 1.33 & 1 & 1.6 & 2.25 & 1 & 4.5 & 0.71 & 1 & 1.25 & 1.33 & 1 & 0.5 \\
C & 0.83 & 0.63 & 1 & 0.5 & 0.22 & 1 & 0.57 & 0.8 & 1 & 2.67 & 2 & 1 \\
\hline
\end{tabular}

The scores are given in a scale of 1 to 9 (Saaty rating scale). The significance becomes more positive while the score gets higher. For example, a high score of price factor means a low ticket price, whereas a high score of Comfort Issues means proportionally high comfort. In Table 5, the comparison of alternatives is presented. It is calculated by proportioning each airline according to its scores. Also all of the four alternative comparisons are consistent. After the AHP calculations, we find the results for priority numbers. These priority numbers give us the customers' priority of selection according to the factors considered. The results of the example problem are shown in Figure 4 and Table 6. 


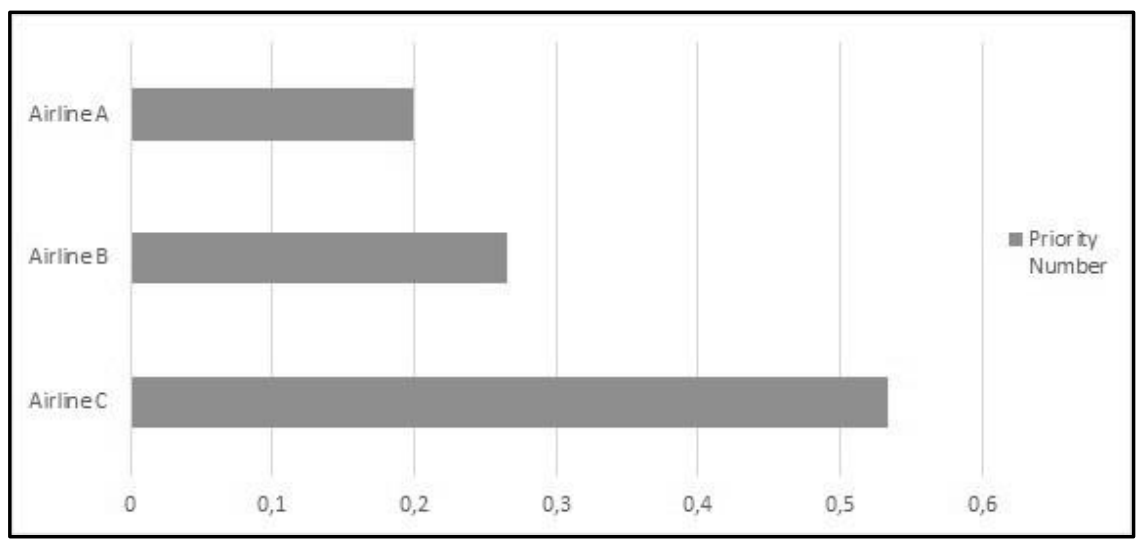

Figure 4. Priority numbers

Table 6. Priority numbers

\begin{tabular}{lc}
\hline & Priority Number \\
\hline A Airline & 0.200 \\
B Airline & 0.266 \\
C Airline & 0.534 \\
\hline
\end{tabular}

As it is seen in the results, the selection priority order of our example airline is $\mathrm{C}>\mathrm{B}>\mathrm{A}$. From the customer's perspective, most probably airline $\mathrm{C}$ will be selected. But it is just a probability. Of course it is impossible to know the exact choice, however, the most probable selection can be estimated by considering our factors. Furthermore, the AHP method can be used to forecast what-if analyses. For example, criteria pairwise comparison matrix values can be changed and new results can be tested. We can carry out what-if analyses for our rivals or for our new target markets and so on.

\section{Conclusions}

Customer value and their perspective are always labile. In the airline business, market dynamics are continuously changing as well. In such a business environment, forecasting carries an extreme importance. This kind of studies can give airlines an edge over their competitors. Besides model can be applied to other areas. In this study factors affecting airline customers' purchase decision are studied. This kind of model can be a complementary element for the factor analysis studies. The results of such factor analyses can be used in integration with the AHP process. Also with an AHP integration, making what-if analyses is feasible. Especially when software packages are used for the AHP, it is simpler and more effective. For example, dynamic effects of factors can be seen by changing the factor score points. This will definitely provide advantages over the rivals in the market.

Also, outputs will be helpful to generate new marketing mixes. As a consequence, this kind of factor analysis and AHP combination will be really effective on marketing and efficient resource planning activities. Understanding customer behaviors and restating strategies are totally essential in such an intensively competitive environment. Either air transportation business or other customer satisfaction based businesses can use that kind of model and study to improve their marketing strategies and market shares.

\section{References}

Atalik, O., \& Aslan, M. (2009). Customer Value Analysis from a Customer's Perspective: Case of Turkish Airlines Domestic Passengers. International Business Research, 2(3), 85-91. http://dx.doi.org/10.5539/ibr.v2n3p85

Benitez, J., Delgado-Galvan, X., Gutierrez, J. A., \& Izquierdo, J. (2011). Balancing consistency and expert Judgement in AHP. Mathematical and Computer Modelling, 54, 1785-1790. http://dx.doi.org/10.1016/j.mcm.2010.12.023

Comert, Y., \& Durmaz, Y. (2006). Tüketicinin Tatmini İle Satın Alma Davranışlarını Etkileyen Faktörlere Bütünleşik Yaklaşım ve Adıyaman İlinde Bir Alan Çalışması. Journal of Yaşar University, 1(4), 351-375. 
Durmaz, Y. (2008). Tüketici Davranışı. Ankara: Detay Yayınları.

Durmaz, Y., Reyhan, B., \& Kurtlar M. (2011). Kişisel Faktörlerin Tüketici Satın Alma Davranışlarına Etkisi Üzerine Bir Araştırma. Journal of Academic Approaches, 2(1), 114-133.

Ercis, A., Unal S., \& Polat, C. (2007). Yaşam Tarzlarının Satın Alma Karar Süreci Üzerindeki Rolü. Atatürk Üniversitesi İktisadi ve İdari Bilimler Dergisi, 21(2), 281-311.

Gurses, F. (2006). Havayolu İsletmeciliğinde Müşteri Tercihlerini Etkileyen Faktörler ve Yerli Yolculara Yönelik Bir Araştırma. Dissertation MS. Balıkesir University, Institute of Social Sciences, Balıkesir, Turkey.

Hoyer, W. D., \& Macinnis, D. J. (1997). Consumer Behavior. Boston: Houghton Mifflin Company.

Islamoglu, A. H. (1999). Pazarlama Yönetimi: Stratejik ve Global Yaklaşım. Istanbul: Beta Basım Yayım Dağıtım A.Ş.

Islamoglu, A. H. (2003). Tüketici Davranışları. Istanbul: Beta Basım Yayım Dağıtım A.Ş.

Odabasi, Y. (1998). Tüketici Davranışı ve Pazarlama Stratejisi. Eskişehir: Anadolu Üniversitesi Yayınları.

Saaty, T. L. (2003). Decision-making with the AHP: Why is the principal eigenvector necessary. European Journal of Operation Research, 145, 85-91. http://dx.doi.org/10.1016/S0377-2217(02)00227-8

Schiffman, L. G., \& Kanuk, L. L. (1987). Consumer Behavior (3rd ed.). New Jersey: Prentice Hall.

THY. (1998). Uçuş ve Yer Emniyet Bülteni. İstanbul.

\section{Appendix}

\section{Demographical Factors of Population and Descriptive Statistics of Items}

Table A1. Demographical factors

\begin{tabular}{cccc}
\hline & Range & Frequency & Percentage \\
\hline Gender & Female & 90 & 23.3 \\
& Male & 297 & 76.7 \\
\hline Age & $15-25$ & 208 & 53.7 \\
& $26-35$ & 151 & 39.0 \\
& $36-45$ & 8 & 2.1 \\
\hline Education Level & $46-55$ & 18 & 4.7 \\
& Above 55 & 2 & 0.5 \\
\hline Primary School & 1 & 0.3 \\
& High School & 15 & 3.9 \\
& Bachelor's Degree & 216 & 55.8 \\
& Undergraduate Degree & 112 & 28.9 \\
& Master's/Doctorate & 43 & 11.1 \\
\hline Income Level & $0-999$ TL & 122 & 31.5 \\
& Above-1999 TL 5000 TL & 95 & 24.5 \\
& $2000-2999$ TL & 111 & 28.7 \\
& $3000-4999$ TL & 54 & 14.0 \\
& & 5 & 1.3 \\
\hline
\end{tabular}


Table A2. Descriptive statistics of items affecting purchase decision

\begin{tabular}{cllcc}
\hline & $\mathrm{N}$ & Mean & Std. Deviation & Variance \\
\hline Price & 387 & 4.6072 & 0.73812 & 0.545 \\
Schedule & 387 & 3.8424 & 1.13743 & 1.294 \\
Flight Connection & 387 & 4.5530 & 0.77470 & 0.600 \\
Catering & 387 & 3.6977 & 1.14903 & 1.320 \\
Technology & 387 & 3.9587 & 0.92649 & 0.858 \\
Baggage Limit & 387 & 3.6279 & 1.23676 & 1.530 \\
Advertisement & 387 & 3.0491 & 1.19808 & 1.435 \\
Corp. Image Q1 & 387 & 3.2868 & 1.09540 & 1.200 \\
Website & 387 & 4.2039 & 0.88459 & 0.783 \\
Corp. Image Q2 & 387 & 3.5426 & 1.16740 & 1.363 \\
Shuttle & 387 & 3.8553 & 1.05778 & 1.119 \\
Call Center & 387 & 2.7700 & 1.16794 & 1.364 \\
Frequent Flier Program & 387 & 3.0646 & 1.26059 & 1.589 \\
Punctuality & 387 & 4.3359 & 0.84915 & 0.721 \\
\hline
\end{tabular}

\section{Copyrights}

Copyright for this article is retained by the author(s), with first publication rights granted to the journal.

This is an open-access article distributed under the terms and conditions of the Creative Commons Attribution license (http://creativecommons.org/licenses/by/3.0/). 